\title{
Os histiócitos e as histiocitoses não Langerhans em dermatologia*
}

\section{Histiocytes and non-langerhans histiocytosis in dermatology}

\author{
Nelson Guimarães Proença'
}

Excelente a revisão sobre histiocitoses não Langerhans, publicada pelos Anais em seu primeiro número de 2003. ${ }^{1}$ No final, os autores expressam seu desejo de "que outros também se interessem em tentar elucidar esse intricado e fascinante campo de estudo". Tive oportunidade de acompanhar alguns casos característicos de histiocitoses, tanto de Langerhans como não Langerhans e escolhi o tema para conferência que pronunciei, em Buenos Aires. ${ }^{2}$

Os autores daquela revisão ilustraram seu trabalho mostrando casos clínicos bastante sugestivos de algumas das histiocitoses não Langerhans, mas não de todas. Pensando que posso contribuir para a documentação iconográfica, enriquecendo ainda mais o conhecimento dos leitores dos Anais, envio agora, com pedido de publicação, os resumos de dois casos que estou tendo a oportunidade de acompanhar por mais de 10 anos.

O primeiro deles é caso de histiocitoma eruptivo generalizado, consultado em 1992. Tratava-se de paciente do sexo masculino, médico de 44 anos, que a partir dos 42 anos apresentou pápulas perfeitamente hemisféricas, medindo entre três e quatro milímetros de diâmetro, de tonalidade róseo-escura, em número de oito, distribuídas pelo tórax (Figura 1), braços e coxas. Como antecedente a ser registrado, uma coagulopatia decorrente de um defeito de agregação plaquetária (as plaquetas não mantêm a adesão entre si). Biópsias foram tomadas para os exames histopatológico e ultramicroscópico. O resultado da histopatologia mostrou presença de denso infiltrado de histiócitos ocupando a derme papilar e reticular. Citoplasma abundante, eosinófilo, finamente granuloso, moderadamente corado pelo PAS, mas negativo em coloração para lípides (Sudan III). Já a ultramicroscopia mostrou interessante aspecto da membrana celular, que apresentava projeções citoplasmáticas interligando células vizinhas. No citoplasma, numero-
The revision published by the Annals in the first edition of 2003, on non-Langerhans histiocytosis was excellent..$^{I}$ The authors concluded by expressing their desire that "others would also be interested in trying to elucidate this intricate and fascinating field of study". I have had the opportunity of treating some characteristic cases of histiocytosis, both Langerhans as well as non-Langerhans and I chose the theme for the talk I gave at a conference in Buenos Aires. ${ }^{2}$

The authors of this revision illustrated their work showing clinical cases most of which but not all were suggestive of non-Langerhans histiocytosis. Considering that I can contribute to the iconographic documentation and thereby enrich still further the knowledge of the Annals readership, I offer for publication, the summaries of two cases that I have followed up for over 10 years.

The first is a case of disseminated eruptive histiocytoma, attended in 1992. It concerned a male patient, 44 year-old doctor, that presented perfectly hemispherical papules with onset at 42 years of age, measuring between three to four millimeters in diameter, with a dark-pink shade, numbering eight in all, distributed in the thorax (Figure 1), arms and thighs. Regarding relevant antecedents, he had suffered coagulopathy due to a defect in the platelet aggregation (adhesion was not maintained between the platelets). Biopsies were performed for histopathological and ultramicroscopic exams. The result of the histopathology showed the presence of a dense infiltration of histiocytes occupying the papillary and reticular dermis. Abundant eosinophilic cytoplasm, finely granular, moderately stained by PAS, but negative in coloration by lipids (Sudan III). While ultramicroscopy revealed an interesting aspect of the cellular membrane, in that it presented cytoplasmatic projections interconnecting neighbor-

Recebido em 03.04.2003. / Received in April, $03^{\text {nt }}$ of 2003.

Aprovado pelo Conselho Consultivo e aceito para publicação em 04.04.2003. / Approved by the Consultive Council and accepted for publication in April, 04 th of 2003.

${ }^{l}$ Ex-Professor Titular e atual Médico Voluntário da Santa Casa de São Paulo. / Ex-Titular Professor and currently Volunteer Doctor at the "Santa Casa de Misericordia" Hospital, São Paulo 
Figura 1: Histiocitoma eruptivo generalizado, lesão recente.

sas estruturas vesiculares morfologicamente identificadas como coma bodies. Ausência de vacúolos lipídicos e de grânulos de Birbeck. Os demais exames laboratoriais foram normais (exceto o estudo da coagulopatia), o estudo lipídico incluído. Evolução: as lesões persistiam inalteradas e após um tempo variável (em geral a partir do segundo ano) iniciavam remissão espontânea, deixando mácula acastanhada residual. Novas pápulas surgiram nos anos seguintes somando ao todo 24 lesões (nos três anos subsequientes). Onze anos após o início do quadro, já não apresenta mais lesões.

O segundo caso é de xantoma disseminado. Paciente do sexo feminino, branca, 24 anos, professora, natural e procedente de São Paulo. Foi acompanhada durante 11 anos, a partir de 1992. Em seus antecedentes pessoais informa ter tido menarca aos 13 anos, mas, no início da puberdade, houve crescimento desigual das mamas: desenvolveuse normalmente a da direita, mas não a da esquerda. Por esse motivo, aos 13 anos foi submetida a tratamento hormonal, durante vários meses, com medicamentos que não soube especificar. Após um ano de tratamento a mama esquerda desenvolveu-se, sendo o tratamento então interrompido. Aos 17 anos surgiram as primeiras lesões cutâneas, nas axilas e, passados alguns meses, também em torno da boca. Aos 21 anos houve aumento e disseminação das lesões, ao redor dos olhos, no pescoço, no abdômen. Não refere qualquer sintoma geral, continuando a desempenhar seu trabalho normalmente. Ao exame foram encontradas lesões em diferentes fases evolutivas. Quando recentes são puntiformes, do tamanho de uma cabeça de alfinete, estando ao lado e entre os folículos pilossebáceos, mas sem deles fazer parte. Assumem aspecto de pápulas e $\operatorname{logo}$ de nódulos (Figura 2), que se

Figura 2: Xantoma disseminado, em seu segundo ano de evolução.

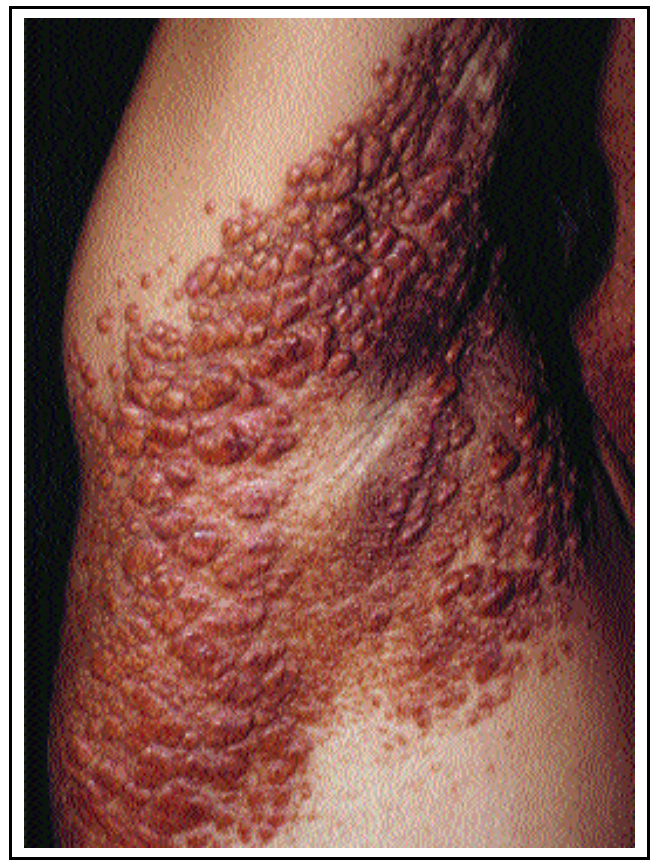

Figure 1: Generalized eruptive bistiocytoma; recent lesion.

ing cells. In the cytoplasm, numerous vesicular structures were morphologically identified as coma bodies. Lipid vacuoles and Birbeck's granules were not present. The other laboratory exams were normal (except for coagulopathy), including lipid tests. Clinical course: the lesions persisted unaffected and after a varying period (in general starting from the second year) they entered into spontaneous remission, leaving a residual brownish stain. New papules appeared during the following years summing 24 lesions altogether (in the three subsequent years). Eleven years after onset of the picture, the patient no longer presents any lesions.

The second case involved disseminated xanthoma. Female patient, white, 24 years of age, teacher, born and resident in Sao Paulo. She was attended for 11 years, starting from 1992. Regarding personal antecedents she reported menarche at 13 years, but at the beginning of puberty there was asymmetrical growth of the mammas: developing normally on the right, but not on the left. For that reason, at 13 years of age she was submitted to hormonal treatment, for several months, with medicines that she could not specify. After one year of treatment the left mamma developed and treatment was then suspended. When 17 years old, the first cutaneous lesions appeared in the armpits and, after several months, also around the mouth. By 21 years of age there were an increase and dissemination of the lesions around the eyes, in the neck and in the abdomen. She did not refer to any general symptoms, continuing to carry out her work as usual. Physical exam showed lesions in different evolutionary phases. When recent they were punctiform, around the size of a pinhead, located next to and between the pilosebaceous follicles, but without involving them. They assumed a papular aspect and soon after one of

Figure 2: Disseminated xanthoma; in the second year of clinical course. 
agrupam para formar amplas placas. São mais exuberantes nas pálpebras, lábios, pescoço e axilas. Em outras regiões interescapular, cavos antecubitais, abdômen, regiões inguinocrurais, subglúteas - as lesões estão em fase inicial, conferindo uma tonalidade amarelada à pele, percebendo-se já a presença de pápulas puntiformes. Na mucosa bucal há acometimento da face interna dos lábios, do dorso da língua e dos pilares do palato. O estudo laboratorial, para lípides inclusive, foi repetidamente normal. Igualmente normal o estudo por imagem (ultra-sonografia abdominal e pélvica, estudo radiológico do esqueleto e tomografia computadorizada de crânio). O exame anatomopatológico mostrou característicos histiócitos xantomisados. A marcação com proteína S100 e CD1 foi negativa. Na ultramicroscopia, presença de vacúolos lipídicos no citoplasma e ausência de grânulos de Birbeck ou de coma bodies. A paciente foi acompanhada até os 35 anos, podendo ser observada lenta, progressiva e parcial involução de lesões, que deixava a pele suprajacente com aspecto residual flácido. Algumas intervenções corretivas foram então praticadas, alcançando resultado estético moderadamente satisfatório. Durante o seguimento a paciente teve gravidez, com nascimento de menina absolutamente normal. Esse caso foi também observado, em seu primeiro ano de evolução, pelo grupo do Hospital do Servidor Público Estadual de São Paulo, tendo sido publicado. ${ }^{3}$

\section{REFERÊNCIAS / REFERENCES}

1. Luz FB, Gaspar AP, Kalil-Gaspar N, Ramos-e-Silva M. Os histiócitos e as histiocitoses não Langerhans (Revisão). An bras Dermatol 2003; 78(1):99-118.

2. Proença NG. Histiocitoses. $49^{\circ}$. Curso Intensivo de Perfeccionamiento Dermatológico para Graduados Prof Dr Luis E Pierini, Buenos Aires, 2000;(Conferência).

3. Sittart JAS; Costa AR; Valente NYS; Criado PR; Mauad MJ. Xantoma disseminado: relato de um caso com extenso acometimento cutâneo. Méd Cut I.L.A.1995;XXIII:319-23. nodules (Figure 2), that grouped together to form extensive plaques. They were more exuberant in the eyelids, lips, neck and armpits. In other areas - interscapular, antecubital spaces, abdominal, inguinocrural and subgluteal - the lesions were in the initial phase, conferring a yellowish tint to the skin and the presence of punctiform papules could already be observed. In the buccal mucous membrane there was involvement of the internal face of the lips, dorsal area of tongue and arch of the palate. Laboratorial tests, including for lipids, were repeatedly normal. Likewise, imaging tests were normal (abdominal and pelvic ultrasound scan, radiological study of the skeleton and computerized tomography of the skull). Anatomicopathological exam showed characteristic xanthomatous histiocytes. Marking with protein S100 and CD1 was negative. Ultramicroscopy revealed the presence of lipoid vacuoles in the cytoplasm and absence of Birbeck's granules or coma bodies. The patient was followed up until 35 years of age and a slow, progressive and partial involution of the lesions was observed, which left the surrounding skin with a flaccid residual aspect. Some corrective interventions were attempted, achieving a moderately satisfactory aesthetic result. During the follow-up the patient underwent a pregnancy, giving birth to an absolutely normal girl. This case was also observed, in its first year of clinical course by a group researchers at the State Public Servant Hospital of São Paulo and was reported in the literature. ${ }^{3}$

\author{
ENDEREÇO PARA CORRESPONDÊNCIA: / MAILING ADDRESS: \\ Nelson Guimarães Proença \\ Rua Prof Artur Ramos, 241, $9^{\circ}$. andar \\ São Paulo SP 01454-011 \\ Tel/Fax:(11) 3032-7573 \\ E-mail:nelson@proencaderm.med.br
}

